International Research Journal of Management, IT \& Social Sciences
Available online at https://sloap.org/journals/index.php/irjmis/
Vol. 7 No. 1, January 2020, pages: 235-241
ISSN: 2395-7492
https://doi.org/10.21744/irjmis.v7n1.841

\title{
Market Reaction Before and After Stipulation of Presidential Regulation Point 55 in 2019
}

Ida Bagus Gede Dananjaya ${ }^{a}$ Ida Bagus Panji Sedana ${ }^{\mathrm{b}}$

Article history:

Submitted: 27 November 2019

Revised: 18 December 2019

Accepted: 14 January 2020

\section{Keywords:}

abnormal return;

capital market;

event study;

Indonesia stock exchange;

trading volume activity;

\begin{abstract}
The purpose of this study is to examine the capital market reaction to the adoption of Perpres no. 552019 with abnormal return and trading volume activity as indicators. This study uses 10 companies listed in the automotive subsector and components in the Indonesia stock exchange in the period of 5 days before and after the adoption of Presidential Decree No. 55 of 2019. The analysis technique used in this study is the Wilcoxone Signed Rank Test and the Paried Sample t-test test. Wilcoxone Signed Rank Test results prove that there are differences in the average negative abnormal return before and after the stipulation of Presidential Regulation no. 552019 based on the results of these tests it can be concluded that investors consider the information as bad news (bad news). Paried Test Results in The t-test sample proves that there is no difference in the average trading volume activity before and after the stipulation of Presidential Regulation no. 555 in 2019 based on these tests it was concluded that it did not trigger stock movements in the capital market that affect the supply and demand of existing shares in the automotive and component sub sector shares.
\end{abstract}

International research journal of management, IT and social sciences (C) 2020. This is an open access article under the CC BY-NC-ND license (https://creativecommons.org/licenses/by-nc-nd/4.0/).

\section{Corresponding author:}

Ida Bagus Gede Dananjaya,

Faculty of Economics and Business, Udayana University, Denpasar, Indonesia.

Email address: idabagusgededananjaya@gmail.com

Udayana University, Denpasar, Indonesia

Udayana University, Denpasar, Indonesia 


\section{Introduction}

Investing in the capital market becomes very attractive because it can get returns and there is also a risk in an investment. The risk level of investment. This is due to fluctuations in stock prices which indicate two possibilities including an increase in prices that can provide capital gains (capital gains) or a decrease in prices that can cause capital losses (capital loss). Eliminating investment risk cannot be done, but investors can avoid or reduce risk by means of analyzing the risk factors of information that can make the capital market react. Information that can affect capital market reactions is all information that is considered important and is able to influence stock prices. Determination of Presidential Regulation No. 55 of 2019 which was set on July 8, 2019, is an event setting regulations that will regulate business activities in the industrial sector and components. The event is information that will be received by investors, to test the information contained in the adoption of Presidential Regulation No. 55 of 2019 is to use an event study. Determination of Presidential Decree No. 55 of 2019 is an information that is classified as semi strong form, the way to test it is using event study by looking for abnormal return and trading volume activity when the event takes place and trading volume activity before and after the adoption of Presidential Regulation No. 55 of 2019 on July 8, 2019, in the shares of the automotive and component sub-sectors on the Indonesia Stock Exchange based on related concepts and theories and empirical facts which were then formulated into hypotheses.

Based on the Signaling theory, the principle of signaling teaches that every action contains information, so it is rooted in the idea of asymmetric information, which says that in some economic transactions, inequality in access to normal market information for the exchange of goods and services. In the context of the event study, which is an observation of stock prices in the capital market to find out whether there is an Abnormal Return obtained by shareholders as a result of a particular event, this signaling theory provides an explanation that each event will contain information that will affect the market (Bialkowski et al., 2006). Establishment of Presidential Regulation No. 55 of 2019 as an event is suspected to have information content that can influence market reactions. The market reaction is indicated by changes in the company's stock price as measured by Abnormal Return. If Abnormal Return is used, it can be said that an announcement which has information content will give Abnormal Return to the market. Conversely, a regulation that does not contain information does not provide Abnormal Returns to the market. According to Nazir (2018), in his study stating there were differences in average Abnormal Returns before and after the event the same results were obtained in the study (Asiri et al., 2015; Ahmed, 2017; Jayaody et al., 2017; Dasilas, 2011; and Chesney et al., 2011). According to Suparmono (2017), in his research states, there is no difference in the average Abnormal Return before and after the event, the same results were obtained in the study (Amelie, 2016; Alsafatar, 2012; Liu, 2016; and Bacon, 2018).

Trading volume is an accepted part of technical analysis. Very high volume trading activities on an exchange will be interpreted as a sign that the market will improve. The increase in the volume of stock trading coupled with an increase in prices is a symptom of a stronger condition of a bullish condition. Trading volume activity is one indicator that is a signal of market reaction to an event (Aggarwal, 2017). Market reaction is not only indicated by changes in stock prices that are reflected in Abnormal Returns, but it is also indicated by changes in trading activities that are reflected in the trading volume of the company's shares. Trading volume can be measured by trading volume activity. TVA can be used to see whether an individual investor evaluates information from an individual. TVA can be used to see whether investors individually assess information from an election as a positive or negative signal to make stock trading decisions. If investors interpret it as a positive signal for this information, then the demand for shares will be higher than the stock offering so that the trading volume will increase. Conversely, if a negative signal appears on the information, then the level of stock demand that occurs will be lower than the level of stock offering so that the trading volume of shares has decreased. According to Adetunji et al. (2017), in his study stated there were differences in average Trading volume activity before and after the event, the same results were obtained in the study (Larcker et al., 2011) and (Chordia \& Swaminathan, 2000). The results which state that there is no difference in average trading volume activity before and after the event are found in the study (Saputra, 2018; Paula et al, 2014; and Nurfadillah \& Nuzula, 2019).

\section{Materials and Methods}

This research is a type of comparative research according to Nazir et al. (2018). Comparative research is a kind of descriptive research that wants to find answers fundamentally about causation, by analyzing the factors that cause or emerge of a particular phenomenon. Comparative research is a type of research used to compare two or more groups 
of certain variables. The object of research is a trait of the object determined by researchers to be studied and then obtain conclusions. From this understanding, it can be explained that the object of research is the source and place we will obtain data. The object of this research is companies listed on the Indonesia Stock Exchange (IDX) automotive sector and component sub-period 2019.

Abnormal Return is an excess of returns that actually occur against normal returns which are expected returns by investors (expected return) (Jogiyanto, 2010). The calculation result of Trading Volume Activity (TVA) reflects the comparison between the number of shares traded with the number of shares outstanding in a certain period (Husnan, 2006). The population in this study are 12 companies listed in the Automotive and Commodity sub-sector index listed on the Indonesia Stock Exchange. Data collection methods used in this study are non-participant observation methods that researchers can make observations as data collectors without getting involved from observed phenomena (Indriantoro \& Supomo, 2009). Data collected through non-participant observation by observing and recording and studying the descriptions of books, journals, theses and accessing PT. Indonesia Stock Exchange (IDX) through www.idx.co.id. The data was obtained in the form of ICMD and other historical reports on the IDX.

\section{Results and Discussions}

Descriptive statistics are used to determine the maximum, minimum, average (mean), and standard deviation of the average variable abnormal Return and trading volume activity at the time before and after the stipulation of Perpres No 55 2019. The results of abnormal return analysis at the time before and after the stipulation of Perpres No 552019 statistically, it can be seen in Table 1 below:

Table 1

Descriptive statistic

\begin{tabular}{llllll}
\hline & $\mathrm{N}$ & Minimum & Maximum & Mean & Std. Deviation \\
\hline AR_Before & 10 & -.005820 & -.005817 & -.00581756 & .000000857 \\
AR_after & 10 & -.000530 & -.000520 & -.00052916 & .000003217 \\
Valid N (listwise) & 10 & & & & \\
\hline
\end{tabular}

Secondary Data, 2019

Table 1 can be seen that statistically, the company's abnormal return (AR) in the five days before the Presidential Decree No. 55 of 2019 has an average of -0.00581756 with an average deviation of abnormal return of 0.000000857 . This shows that there is an average negative return, which means that the actual return that occurs is lower than the expected return. In the company's abnormal return (AR) five days after the Presidential Decree No. 55 of 2019 has an average of $-0,00052916$ with an average deviation of abnormal return of 0.000003217 . This shows that there is an average negative return which means that the actual abnormal return that occurs is lower than the expected abnormal return.

The minimum average value of abnormal return or the lowest average abnormal return before the Presidential Decree No. 55 of 2019 occurred in ASII, AUTO, BRAM, GJTL, IMAS, INDS, LPIN, MASA, and SMSM companies with a value of -0.00581729 , while the maximum average value of abnormal return or the highest average abnormal return occurs in PRAS companies with a value of -0.00582. In the period after the stipulation of Perpres No. 55 of 2019, the minimum average value of abnormal returns occurs in ASII, AUTO, BRAM, GJTL, IMAS, INDS, LPIN, MASA, and SMSM companies with a value of $-0,000530$, while the maximum value average abnormal return occurs in PRAS companies with a value of $-0,000520$.

The results of trading volume activity analysis before and after the stipulation of Perpres No. 52019 statistically, can be seen in Table 2 below.

Table 2

Descriptive statistic

\begin{tabular}{llllll}
\hline & $\mathrm{N}$ & Minimum & Maximum & Mean & Std. Deviation \\
\hline TVA_Before & 10 & .000002 & .001401 & .00043026 & .000480995 \\
TVA_After & 10 & .000000 & .000925 & .00032264 & .000340619 \\
Valid N (listwise) & 10 & & & &
\end{tabular}

Secondary Data, 2019

Dananjaya, I. B. G., \& Sedana, I. B. P. (2020). Market reaction before and after stipulation of presidential regulation point 55 in 2019. International Research Journal of Management, IT and Social Sciences, 7(1), 235-241. https://doi.org/10.21744/irjmis.v7n1.841 
In trading volume activity (TVA) the company five days before the Presidential Decree No. 55 of 2019 has an average of 0,00043026 with an average deviation of Trading volume activity of 0,000480995. In the five days after the Presidential Decree No. 55 of 2019, there was an average Trading volume of activity of 0,00032264 with an average deviation of 0,000340619 . This shows that there is an average positive Trading volume activity which means that the actual Trading volume activity that occurs is higher than the expected Trading volume activity.

The minimum average value of Trading volume activity or the lowest average trading volume activity either before or after the stipulation of Perpres No. 55 of 2019 occurred in BRAM companies (Indo Kordsa Tbk.) With a value of 0.00000164 prior to the stipulation of Perpres No. 55 years 2019, while at the time after the enactment of Perpres No. 55 of 2019 had a value of 0.00002727 . The maximum average value of Trading volume activity or the highest average trading volume activity before or after the stipulation of Perpres No. 55 of 2019 occurs in GJTL companies (Gajah Tunggal Tbk.) With a value of 0.00140126 prior to the stipulation of Perpres No. 55 of 2019, whereas at the time after the stipulation of Perpres No 552019 it has a value of 0,00092482. Test the hypothesis about the difference in abnormal returns on the shares of companies incorporated in the automotive sub-sector and components before and after the adoption of Presidential Regulation number 55 in 2019 using the Wilcoxon Signed Rank Test which is a method to test the difference in average abnormal returns before and after the determination of Perpres No 55 years 2019. The Wilcoxon test results can be seen in the following Table 3 .

Table 3

Wilcoxon test results average abnormal return before and after the stipulation of Perpres No. 55 of 2019

\begin{tabular}{ll}
\hline & AR After-AR Before \\
\hline$Z$ & $-3.051^{\mathrm{a}}$ \\
Asymp. Sig. (2-tailed) & .002 \\
\hline Secondary Data, 2019
\end{tabular}

Secondary Data, 2019

Based on the results of processing using SPSS version 18 can be seen in Table 3 shows the average test results Sig. (2tailed) $0.002<0.05$. Based on the acquisition, it can be concluded that there is a difference in the average Abnormal Returns in the shares of the Automotive Sub-sector and its Components before and after the stipulation of Perpres no 552019 , then $\mathrm{H} 1$ is accepted.

The second hypothesis testing uses paired samples t-test which is processed with SPSS 18.0 software for windows. Hypothesis test results of differences in trading volume activity before and after the adoption of Presidential Regulation No. 5 of 2019 can be seen in Table 4 below:

Table 4

Paired samples test results t-test average trading volume activity before and after the stipulation of Perpres No 552019

\begin{tabular}{|c|c|c|c|}
\hline & & & $\begin{array}{l}\text { Pair } 1 \\
\text { TVA Before - TVAfter }\end{array}$ \\
\hline \multirow{5}{*}{ Paired Differences } & Mean & & 0,000107619 \\
\hline & Std. Deviation & & 0,000181552 \\
\hline & Std. Error Mean & & 0,000057412 \\
\hline & $95 \%$ Confidence Interval & Lower & $-0,000022256$ \\
\hline & of the Difference & Upper & 0,000237493 \\
\hline $\mathrm{T}$ & & & 1,875 \\
\hline Df & & & 9 \\
\hline sig. (2-tailed) & & & 0,094 \\
\hline
\end{tabular}

Secondary Data, 2019

Table 4. shows the value of sig. (2-tailed) 0.094 , which has a value of more than 0.05 . This value states that there is no difference in Trading Volume Activity (TVA) in the shares of construction and building sub-sectors before and after the stipulation of Perpres no 55 of 2019, because of sig. (2-tailed) $0.094>0.05$ then $\mathrm{H} 2$ is rejected. 


\section{Hypothesis I}

The characteristics of the capital market reflect sensitive investor behavior. This behavior is based on information received by investors that can give a positive signal or a negative signal, thus helping investors in making investment decisions. One of the information received by investors is information on the stipulation of regulation no. 55 in 2019. The hypothesis regarding the stipulation of regulation no. 55 in 2019 to the average abnormal return states that there is a significant difference in average abnormal return before and after the stipulation of regulation no. 55 years 2019. This is indicated by the significance value $<0.05$ then $\mathrm{H} 1$ is accepted. The results of tests conducted on the significance of Abnormal Returns of shares during the study period indicate that there is an Abnormal Return that is negative around the event period ie, on the day (t-3). The emergence of Abnormal Return has a significant negative value in the $t-3$ period before the promulgation of Presidential Decree No. 55 of 2019, possibly because the policy is not favored by investors, so investors assess the information as (bad news). The results of this test are consistent with research conducted by Nazir et al. (2018); Asiri (2015); Jayakody (2017); Dasilas \& Laventis (2011); and Chesney et al., (2011). The results of these studies indicate that there are significant abnormal abnormal returns before and after the event. The results of this study are not consistent with the results of research conducted by Supramono et al. (2017); Charles \& Darné (2016); Al-Shattarat (2012); and Liu (2018).

\section{Hypothesis II}

Capital market reaction to information can be observed using trading volume activity indicators. Certain information or events can trigger stock movements in the capital market which will affect the supply and demand of shares. The hypothesis regarding the stipulation of Presidential Regulation no. 55 in 2019 to the average trading volume activity states that there is no significant difference in the trading volume of stock activity before and after the stipulation of Presidential Regulation no. 55 in 2019. This is indicated by the significance value $>0.05$ then $\mathrm{H} 2$ is rejected. The results obtained indicate that the information contained in Presidential Regulation no. 55 of 2019 did not trigger the movement of shares in the capital market that affected the supply and demand of shares in the automotive and component sub sector shares. The results of this research are the same as the results of research conducted by Saputra (2018); Paula \& Paulus (2014); and Nurfadillah \& Nuzula (2019). This study has different results from the results of research conducted by Larcker et al., (2011) and Chordia \& Swaminathan (2000).

\section{Conclusion}

The results of this study provide information that decree No. 55 of 2019 which caused the Indonesian capital market to be most prominent in the automotive subsector and its components reacted to this information so that there were differences in the average negative abnormal returns before and after the event. Statistic test using Wilcoxon Signed Rank Test shows significance $<0.05$, this is because the market considers the decree of Presidential Regulation number 55 of 2019 has bad information content (bad news). Other findings in this study are trading volume activity at the time of the presidency of Presidential Decree no. 55 in 2019. Data analysis results in no difference in the average trading volume activity before and after the stipulation of Presidential Regulation no. 55 in 2019. This is indicated by the significance> 0.05 which means there is no significant difference in the volume of trading activity both before and after the adoption of Presidential Regulation no. 55 2019. These findings are used as information input to investors in the capital market especially in the automotive subsector and components during the stipulation period of Presidential Regulation No. 55 of 2019. Obviously, with the results of this study, it is expected that investors can make the right investment decisions in the future.

\section{Research limitation}

The limitation of this study is the calculation method that only uses the Market Adjusted Model, this research area that uses companies that are based on the automotive and component sectors. As well as this research using an 11 day window period. Future studies are expected to use a wider research area and different calculation methods such as the mean adjusted model and the market model.

Dananjaya, I. B. G., \& Sedana, I. B. P. (2020). Market reaction before and after stipulation of presidential regulation point 55 in 2019. International Research Journal of Management, IT and Social Sciences, 7(1), 235-241. https://doi.org/10.21744/irjmis.v7n1.841 
Conflict of interest statement

The authors declared that they have no competing interests.

Statement of authorship

The authors have a responsibility for the conception and design of the study. The authors have approved the final article.

Acknowledgments

We are grateful to two anonymous reviewers for their valuable comments on the earlier version of this paper. 


\section{References}

Adetunji, A., Adetunji, A., Adeleke, E., \& Madubuike, S. (2017). Deregulation: the effect of market-led approach to Nigerian universities management. International Journal of Social Sciences and Humanities, 1(1), 1-8. https://doi.org/10.29332/ijssh.v1n1.6

Aggarwal, R. (2017). Different avenues of capital market (secondary market) available for investing in market of yamuna nagar. International Research Journal of Management, IT and Social Sciences, 4(3), 34-50.

Ahmed, W. M. (2017). The impact of political regime changes on stock prices: the case of Egypt. International Journal of Emerging Markets. https://doi.org/10.1108/IJoEM-12-2015-0258

Al-Shattarat, W. K., Al-Khasawneh, J. A., \& Al-Shattarat, H. K. (2012). Market reaction to changes in dividend payments policy in Jordan. Journal of Applied Business Research (JABR), 28(6), 1193-1210. https://doi.org/10.19030/jabr.v28i6.7335

Asiri, B. K. (2015). Investors' to Reaction to Marketing and Financial Announcements in the Telecommunication Sector. Journal of Applied Finance and Banking, 5(3), 123.

Bialkowski, M. E., Uthansakul, P., Bialkowski, K., \& Durrani, S. (2006). Investigating the performance of MIMO systems from an electromagnetic perspective. Microwave and Optical Technology Letters, 48(7), 1233-1238. https://doi.org/10.1002/mop.21664

Charles, A., \& Darné, O. (2016). Stock market reactions to FIFA World Cup announcements: An event study.

Chesney, M., Reshetar, G., \& Karaman, M. (2011). The impact of terrorism on financial markets: An empirical study. Journal of Banking \& Finance, 35(2), 253-267. https://doi.org/10.1016/j.jbankfin.2010.07.026

Chordia, T., \& Swaminathan, B. (2000). Trading volume and cross-autocorrelations in stock returns. The Journal of Finance, 55(2), 913-935. https://doi.org/10.1111/0022-1082.00231

Dasilas, A., \& Leventis, S. (2011). Stock market reaction to dividend announcements: Evidence from the Greek stock market. International Review of Economics \& Finance, 20(2), 302-311. https://doi.org/10.1016/j.iref.2010.06.003

Husnan, S. (2006). Teori dan Penerapan (Keputusan Jangka Panjang). Edisi Keempat. Yogyakarta: BPFE.

Indriantoro \& Supomo. (2009). Metode Penelitan. Jakarta: Gramedia

Jayakody, S. G. (2017). The impact of the Sri Lankan civil war on the stock market performances. International Journal of Economics and Financial Issues, 7(1), 394-402.

Jogiyanto, H. (2010). Teori portofolio dan analisis investasi (edisi ketujuh). Yogyakarta: BPFE.

Larcker, D. F., Ormazabal, G., \& Taylor, D. J. (2011). The market reaction to corporate governance regulation. Journal of financial economics, 101(2), 431-448. https://doi.org/10.1016/j.jfineco.2011.03.002

Liu, J., Sarkar, S., Kumar, S., \& Jin, Z. (2018). An analysis of stock market impact from supply chain disruptions in Japan. International Journal of Productivity and Performance Management. https://doi.org/10.1108/IJPPM-062016-0104

Nazir, M. S., Khan, M. K., Akram, A., \& Ahmed, I. (2018). Impact of Political and Terrorist Events on Stock Market Returns: A Case Study in South Asian Context. Journal of Political Studies, 25(1), 179-200.

Nurfadillah, L. F., \& Nuzula, N. F. (2019). Analisis dampak ex-dividend date pada pembayaran dividen terhadap abnormal return (Studi Pada Perusahaan yang Terdaftar dalam Indeks IDX High Dividend 20 Tahun 2018). Jurnal Administrasi Bisnis, 72(1), 91-99.

Paula, A. \& Paulus, S. K. (2014). Perbedaan Abnormal Return Dan Trading Volume Activity Saham Sebelum dan Sesudah Reverse Split. Management Insight, Vol 7, No 1. pp. 1-11. ISSN 1978-3884

Saputra, I. (2016). Analisis Perbedaan Rata-Rata Trading Volume Activity Saham Sebelum Dan Sesudah Pemilu Presiden Dan Wakil Presiden Tahun 2014 (Event Study Pada Saham Lq-45 Di Bursa Efek Indonesia Periode 29 Juni-19 Juli 2014). Dinamika Ekonomi-Jurnal Ekonomi dan Bisnis, 9(1), 76-86.

Supramono, S., Wilis, W., \& Utami, I. (2017). Market reaction to cabinet reshuffle: The Indonesian evidence. International Journal of Economics and Financial Issues, 7(5), 183.

Dananjaya, I. B. G., \& Sedana, I. B. P. (2020). Market reaction before and after stipulation of presidential regulation point 55 in 2019. International Research Journal of Management, IT and Social Sciences, 7(1), 235-241. https://doi.org/10.21744/irjmis.v7n1.841 